\title{
Comparison of the Immunohistochemical Expression of Caveolin-1 in Endometrial Carcinoma, Endometrial Intraepithelial Neoplasia, Endometrial Hyperplasia, and Normal Endometrium
}

\author{
-DDuygu AYAZa, \\ (1)Gülden DINIZ \\ - SSibel DEMIR KEÇECIc, \\ DDudu SOLAKOĞLU KAHRAMANa \\ DS Sevil SAYHANa \\ aPathology Laboratory, \\ İzmir Tepecik Training and \\ Research Hospital, \\ 'Department of Pathology, \\ İzmir Democracy University \\ Faculty of Medicine, \\ İmir, TURKEY \\ 'Clinic of Pathology, \\ Manisa Merkez Efendi State Hospital, \\ Manisa, TURKEY
}

Received: 23 Aug 2019

Received in revised form: 29 Nov 2019

Accepted: 29 Nov 2019

Available online: 29 Nov 2019

\section{Correspondence:}

Gülden DiNiZ

İzmir Democracy University

Faculty of Medicine,

Department of Pathology,

İmir, TÜRKIYE

gulden.diniz@idu.edu.tr

\begin{abstract}
Objective: This retrospective study was designed to evaluate the importance of tissue expressions of caveolin-1 (Cav-1) known as signal regulator in differential diagnosis of endometrial lesions. Material and Methods: A total of 65 patients with normal endometrium (11 proliferative and 10 secretory epithelium, 32.3\%), endometrial hyperplasia without atypia $(\mathrm{EH})(\mathrm{n}=11,16.9 \%)$; atypical endometrial hyperplasia/ endometrioid intraepithelial neoplasia (AEH/EIN) (n=11; 16.9\%) and endometrial carcinoma (EC) $(n=22 ; 33.8 \%)$ were recruited for the study. Sections prepared from biopsy materials or hysterectomy specimens of the patients were immunohistochemically processed, stained, and examined for the presence of caveolin- 1 expression. The positive association between immunohistochemical staining of caveolin-1 and its relationship with characteristic features of lesions and age of the patients were investigated. Results: The mean age of the patients was $49.1 \pm 8.5$ years. Stromal fibroblasts were positively stained for Cav-1 in 26 (40\%) cases, and stromal expressions of Cav-1. Stromal Cav-1 expressions were detected in indicated cases with EH (36.4\%), EIM (27.3\%), and EC $(68.2 \%)$, while only in $19 \%$ of normal endometrial biopsy specimens. It was determined that if the tumor becomes more invasive, then its stromal Cav- 1 expression reaches to statistically significantly higher levels $(\mathrm{p}=0.001)$. Conclusion: Our findings demonstrated that stromal Cav-1 expression could be used as a marker for malignancy and invasiveness of endometrial neoplasms.
\end{abstract}

Keywords: Caveolin-1 (Cav-1); proliferative endometrium (PE);

secretory endometrium (SE); endometrial hyperplasia without atypia (EH); atypical endometrial hyperplasia/endometrioid intraepithelial neoplasia (AEH/ EIN); type I and type II endometrial cancer (EC)

aveolin-1 (Cav-1) is a principal scaffolding protein of caveolae which are specialized flask-shaped invaginations of cell membranes rich in proteins. Cav-1 involves in the pathogenesis of several cancer types and assume functions in the management and organization of signaling molecules associated with cell survival, proliferation, angiogenesis, and metastasis. ${ }^{1-4}$ As a well- known fact, tumor-associated stroma assumes an important role in the development of several cancer types. ${ }^{3-8}$ Previously, loss or gain of Cav-1 expression in peritumoral stroma of several tumors was associated with poor outcome..$^{3-7}$ However, Cav-1 acts as either a tumor supressor gene or an oncogene. By interacting with the signaling molecules, it may function as a moderately effective oncoprotein or a tumor supressor protein. Therefore, the role of Cav-1 in many tumors still remains as a very controversial issue. Current and future researches related to peritumoralstromal expression of Cav-1 will most likely lead to the emergence of a new 
diagnostic, and prognostic molecular marker which will contribute to the treatment of different malignancies. ${ }^{8,9}$

Endometrial cancer is (EC) the most frequently seen gynecologic malignancy and nearly 40,000 new cases are diagnosed each year. Approximately $90 \%$ of endometrial cancer cases are sporadic and the remaining $10 \%$ are hereditary. It is mostly seen during postmenopausal period. ${ }^{10}$ According to their clinicopathological and molecular- genetic characteristics, endometrial carcinomas are divided into 2 main categories as type 1 and type 2 . Type 1 carcinomas are associated with unmet estrogenic stimulation as in cases with obesity and exogenous estrogen use. The prototype of type 1 carcinoma is endometrioid type endometrial carcinoma (ETEC), which makes up 70-80\% of all endometrial carcinomas. Type 2 carcinomas are not associated with estrogenic stimulation and the most common form is serous carcinoma. ${ }^{11}$ The classification of endometrial neoplasms was updated in 2014. According to the 2014 classification of World Health Organization (WHO), the precursor lesions of endometrial carcinomas were defined as endometrial hyperplasia (EH) and atypical hyperplasia/endometrioid intraepithelial neoplasia (AEH/ EIN). The risk of endometrial carcinoma is increased by 3-4 times in hyperplasia without atypia, whereas, tumor is detected soon after hysterectomies performed in patients diagnosed with $\mathrm{AEH} / \mathrm{EIN}$ or during several years of followup. ${ }^{11-13}$

The aim of this study was to investigate the expression of Cav-1 in different endometrial lesions using immunohistochemical methods and to evaluate a possible relationship between levels of Cav1 expression, and histopathological types of the lesions.

\section{MATERIAL AND METHODS}

\section{STUDY DESIGN}

This cross-sectional study was carried out at the pathology departments of a tertiary care center. A total of 65 patients with normal endometrium (11 proliferative and 10 secretory epithelium, 32.3\%),
EIN ( $\mathrm{n}=22 ; 33.8 \%)$ and EC ( $\mathrm{n}=22 ; 33.8 \%)$ were included in this study. Sections prepared from biopsy materials or hysterectomy specimens of the patients were immunohistochemically processed, stained, examined for the presence of Caveolin 1. Approval from the local institutional review board was obtained prior to the study (21/4- 29.12.2015). The study was performed in accordance with the principles of WMA Declaration of Helsinki Ethical Principles for Medical Research Involving Human Subjects. The intensity, proportion, and location of immunohistochemical staining of Cav-1 and its association with patients' age and types of lesions were investigated.

\section{IMMUNOHISTOCHEMICAL EVALUATION OF CAVEOLIN-1}

Expression levels of Cav-1 were determined by immunostaining $5-\mu \mathrm{m}$ sections from formalinfixed, paraffin-embedded endometrial tissue samples, and the staining intensities of only demonstrative tissue samples or tumor sections previously stained with H\&E dye were evaluated. Immunohistochemistry was perfomed using streptavidine- biotin peroxidase method (Invitrogen, Camarillo, 85-9043, USA). Before immunostaining, tissue sections were baked overnight at $60^{\circ} \mathrm{C}$, dewaxed in xylene and exposed to graded alcohol for gradual hydration. The sections were treated using heat-induced epitope retrieval method in microwave (in $10 \mathrm{mM} / \mathrm{L}$ citrate buffer, $\mathrm{pH}$ 6.0, for 20 minutes, followed by cooling at room temperature for 20 minutes). Blocking of endogenous peroxidase and biotin was performed. Samples were incubated with primary anti-Cav-1 antibodies (Novus Biologicals, Littleton Co, NB100-615, USA) at a dilution of 1:200 for 60 minutes. Negative controls were analyzed on adjacent sections incubated using non- immune mouse serum devoid of primary antibody. Results of immunostaining performed to detect stromal Cav-1 expressions by tumor cells, endothelial cells or stromal cells were evaluated independently from their histological characteristics. Cav-1 immunoreactivity was also observed in the vascular endothelial cells, and accepted as internal positive control. 


\section{STATISTICAL ANALYSIS}

Statistical analysis was carried out by using SPPS 20.0 software. Descriptive characteristics and frequencies of all parameters were evaluated prior to statistical analysis. Correlations between categorical variables were tested with chi-square test. Mann-Whitney U test was applied for intergroup comparisons. A p value of $<0.05$ was considered to be statistically significant.

\section{RESULTS}

Sixty-five patients aged between 27 and 67 years (mean age, $49.1 \pm 8.5 \mathrm{yrs}$ ) were enrolled in this study. Patients: The cases were histologically diagnosed as proliferative endometrium $(\mathrm{PE})(\mathrm{n}=11$; $16.9 \%)$, secretory endometrium (SE) ( $\mathrm{n}=10$; $15.4 \%)$, endometrial hyperplasia without atypia $(\mathrm{EH})((\mathrm{n}=11 ; 16.9 \%)$, atypical endometrial hyperplasia/ endometrioid intraepithelial neoplasia $(\mathrm{AEH} / \mathrm{EIN}))((\mathrm{n}=11 ; 16.9 \%)$, and EC $(\mathrm{n}=22$, $33.8 \%)$. The mean ages of the patients were as follows: PE (45.18 \pm 3.40$), \quad S E(42.1 \pm 6.87), \quad \mathrm{EH}$ $(46.09 \pm 4.20), \quad$ EIN $(.0 \pm 8.83)$, type 1 EC (55.09 \pm 6.64$)$, and type 2 EC $(54.64 \pm 10.86)$. The proportion of type 1 and type 2 EC was equal ( $\mathrm{n}=11,16.9 \%$ ). Cav-1 immunoreactivity was also observed in the vascular endothelial cells (Figure 1 ), and accepted as internal positive control. Stromal fibroblasts were positively stained for Cav-1 in 26 cases (40\%) (Figure 2). Stromal Cav-1 expression was determined in $27.3 \%$ of EINs and $68.2 \%$ of ECs, and in $19 \%$ of normal endometrial specimens and $36.4 \%$ of EHs (Table 1). In addition statistically significantly higher levels of stromal Cav-1 expression (Figure 3) were detected in specimens with high- grade (type II) EC ( $n=9,81.8 \%)$ relative to those with low grade (type I) EC ( $\mathrm{n}=6$, $54.5 \%)(\mathrm{p}=0.002)$. Statistically, it was determined that if the tumor becomes more invasive then a higher invasive potential also it gains the propensity potential to express stromal $\mathrm{Cav}-1$ protein $(\mathrm{p}=0.015)$ (Figure 4). These findings have demonstrated that stromal Cav-1 expression may be used as a marker for agresiveness of endometrial neoplasms.

\section{DISCUSSION}

As documented in various studies, Cav- 1 protein detected in different neoplasms has a complex and controversial role in cell proliferation, tumor development, and progression. ${ }^{14,15}$ It has been also shown that Cav-1 expression decreases during development of breast, ovary, colon, and lung tumors. ${ }^{14}$ Besides, re-expression of Cav-1 alters the transformed phenotype of mammary, colon and ovarian carcinoma cells. ${ }^{15-17}$ As a tumor suppressor protein Cav-1 promotes cell death possibly by blocking signaling pathways aberrantly activated in cancer cells. ${ }^{17}$ Most authors suggested that cav1 positive tumor cells served as tumor promoters by these signaling pathways. ${ }^{7,14}$ In the present study, we didn't determine Cav-1 positive epithelial cells and/or tumor cells. Therefore we couldn't determine any statistical significant relationship between the presence of Cav-1 expression in the tumor cells and the tumor behaviors.

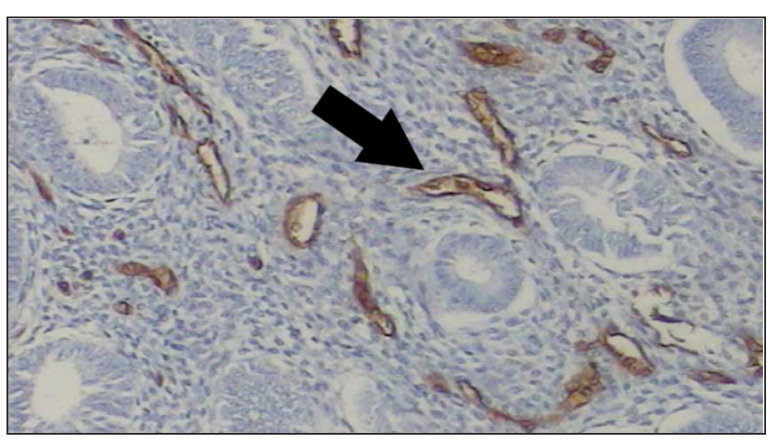

FIGURE 1: Note the perivascular Cav- 1 expression (arrow) in an EIN (DABx 200).

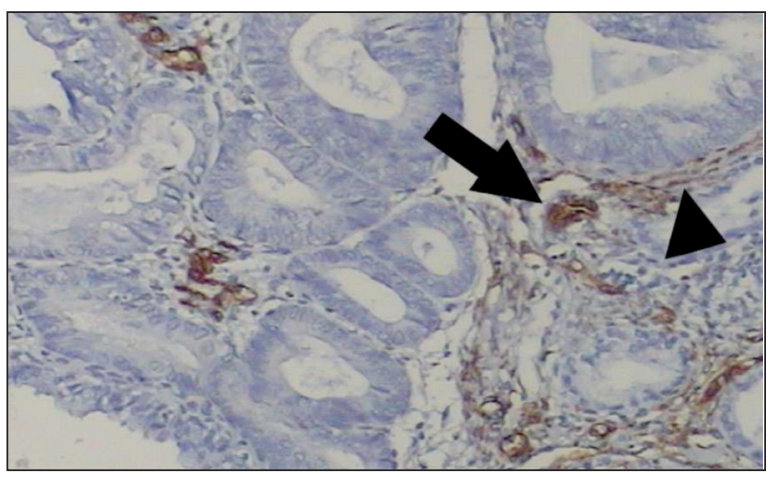

FIGURE 2: Perivascular (arrow) and focal stromal (arrow head) Cav-1 expression in a Type $1 \mathrm{EC}$ (DABx 200). 


\begin{tabular}{|c|c|c|c|}
\hline \multicolumn{4}{|c|}{$\begin{array}{l}\text { TABLE 1: Cav-1 expression according to } \\
\text { the endometrial lesions. }\end{array}$} \\
\hline \multirow[b]{2}{*}{ Pathology } & \multicolumn{3}{|c|}{ Stromal Cav- 1 immune staining } \\
\hline & Positive (n/\%) & Negative (n/\%) & $\mathrm{p}^{*}$ \\
\hline \multirow[t]{2}{*}{ Normal } & $1(9.1 \%)$ & $10(90.9 \%)$ & 0.256 \\
\hline & $3(30 \%)$ & $7(70 \%)$ & \\
\hline $\mathrm{EH}$ & $4(36.4 \%)$ & $7(63.6 \%)$ & 0.397 \\
\hline AEH/ EIN & $3(27.3 \%)$ & $8(72.7 \%)$ & 0.667 \\
\hline EC & $15(68.2 \%)$ & $7(31.8 \%)$ & 0.015 \\
\hline$p^{*}$ & 0.002 & & \\
\hline
\end{tabular}

${ }^{*}$ Chi-Square test.

PE: Proliferative endometrium, secretory endometrium, SE: Secretory endometrium, EH: Endometrial hyperplasia, AEH/EIN: Atypical hyperplasia/endometrioid intraepithelial neoplasia ve EC: Endometrial carcinoma.

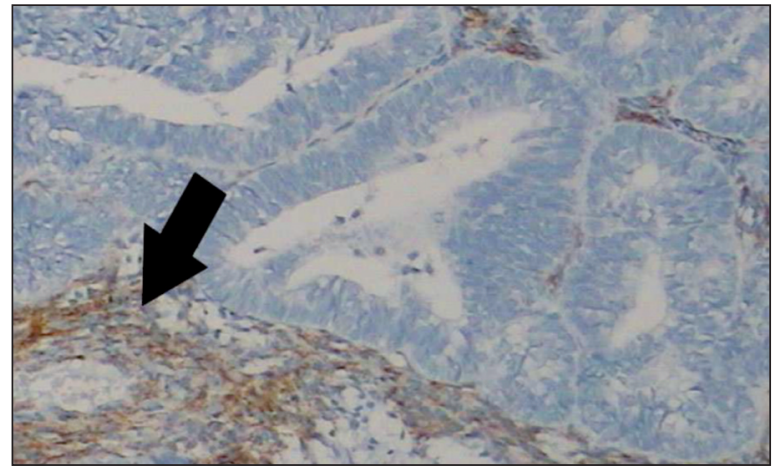

FIGURE 3: Diffuse stromal (arrow) Cav-1 expression in a Type 2 EC (DABx 200).

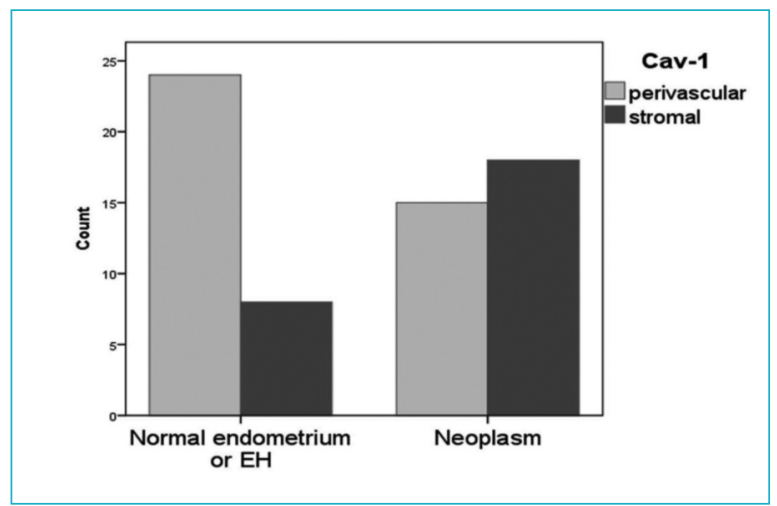

FIGURE 4: The stromal Cav-1 expression is higher in the EIN and EC than normal endometrium and $\mathrm{EH}$ (Chi-Square test, $\mathrm{p}=0.015$ ).

Cav-1 also promotes anchorage- independent growth, cell proliferation, multi-drug resistance cell polarization, migration and metastatic potential of cancer cells. Therefore initial decrease in Cav-1 expression may be a reversible process, whereby increased expression of Cav-1 at later stages has been associated with elevated metastatic potential in colon, lung and prostate cancer cells and poor prognosis for prostate or colon cancer patients. ${ }^{14}$ Based on these data, functions of Cav-1 may change rather dramatically during tumor progression. ${ }^{18-20} \mathrm{We}$ also determined the stromal Cav-1 expression dramatically changed according to the types of the lesions. Cav-1 expression was found in the majority of tumors when compared with specimens of normal endometrium and endometrial hyperplasia.

Tumor microenvironment plays an important role in the onset and progression of malignancy. Cancer cells secrete polypeptide signaling molecules and proteases, increase microvessel density, number of reactive fibroblasts and different inflammatory cells. Cancer-associated fibroblasts lead to changes in the extracellular matrix. This epithelial-mesenchymal transition may result in development of a more aggressive phenotype in the surrounding epithelial cells. ${ }^{20,21}$ Although the actual mechanism of this relationship is not fully clarified yet, obviously transforming growth factor $\beta$ (TGF- $\beta$ ) assumes a major role in cell development and tumorigenesis. ${ }^{21}$ Some studies have shown that decreased stromal Cav-1 levels alter tumor development and angiogenesis. ${ }^{22-24}$ In most English literature, decreased expression of stromal Cav-1 has been reported to play a negative role in cancer transformation. Although the actual mechanism is unknown, many oncogenes such as SRC, RAS, BCR-ABL, transcriptionally downregulate Cav-1 expression. Similarly it was shown by the functional studies that down-regulation of stromal Cav1 expression is likely to alter stromal influences on tumor epithelium, tumor angiogenesis, and cholesterol and androgen metabolism. Previous results indicated that Cav-1 down-regulation in the stroma, which coincides with increased expression of the some reactive marker, induces a number of gene alterations, including up-regulation of TGF$\beta 1$ and down-regulation of some genes related with a pro-angiogenesis effect. It was also shown that Cav-1 silencing stimulates proliferation and provokes oncogenic cell signaling in cancer stromal cells, coincident with increased levels of intracel- 
lular cholesterol and activation of steroidogenic enzymes. These stromal alterations result in increased tumor cell migration. ${ }^{3}$ Recent studies have drawn more attention to caveolin- 1 expression in peritumoral stromal cells relative to its expression in tumor cells. ${ }^{7}$ Indeed Goetz et al. suggested that there may be an important role for stromal Cav-1 in promoting tumor progression and metastasis. ${ }^{25,26}$ But in the most other studies, loss of stromal Cav1 expression in association with the increased tumoral Cav-1 expression, has been reported to be closely related with poor outcome in different malignancies. ${ }^{20-22,25}$ Our similar observation of decreased levels of Cav-1 expression in peritumoral stroma, consistent with recent reports, was associated with the higher stage of endometrial neoplasms. This finding may indicate that the Cav-1 expressions is a feature of invasive tumors.

In this study, we found Cav-1 positivity only in perivascular tissue in most cases with normal endometrium and endometrial hyperplasia. Contrarily, most of the tumors had stromal Cav-1 positivity. The relationship between tumor prognosis and stromal Cav-1 expression could not be evaluated due to the lack of patient follow-up. The most important limitation of this study was the scarce number of cases. The absence of patient follow-up is another limitation of our study.

There are very few studies related to Cav 1 expression in normal endometrium and endometrial carcinoma. On the contrary to our study, Diaz Valdivia et al. detected Cav-1 in stromal cells of the normal proliferative endometrium, while mainly in epithelial cells in cases with endometrial hyperplasia and endometrial carcinomas. ${ }^{14}$ Since the authors did not detect a significant change in protein levels in cases with Stages 1, 2, and 3, they stated that increased Cav-1 levels could not be accepted as a marker for tumor progression. ${ }^{14}$ In our study, there was no patient follow-up, either. However, we found increased stromal Cav-1 expression in type 2 carcinoma, which has a poor prognosis. Therefore, we assumed that Cav-1 may be a prognostic marker.

Type 1 and type 2 endometrial carcinomas are differentiated from each other by the genetic changes they manifest rather than their morphological and clinical features. ${ }^{10}$ Endometrioid and non-endometrioid endometrial carcinomas are associated with mutations in independent gene clusters. PTEN, K-ras and $\beta$-catenin mutations have been detected in endometrioid type endometrial carcinomas, while anoploidy and P53 mutations have been observed in non-endometrioid carcinomas. ${ }^{26}$ In our study, we found stromal caveolin- 1 expressions at different rates in type 1 and type 2 endometrial carcinomas. This may be due to differences in genetic and pathogenetic characteristics of the tumors.

\section{CONCLUSION}

In conclusion, even in a limited number of cases, stromal Cav-1 expression has been found to be associated with aggressive- malignant tumors, and we suggest that these results should be supported by studies performed in larger series.

\section{Source of Finance}

During this study, no financial or spiritual support was received neither from any pharmaceutical company that has a direct connection with the research subject, nor from a company that provides or produces medical instruments and materials which may negatively affect the evaluation process of this study.

\section{Conflict of Interest}

No conflicts of interest between the authors and / or family members of the scientific and medical committee members or members of the potential conflicts of interest, counseling, expertise, working conditions, share holding and similar situations in any firm.

\section{Authorship Contributions}

Idea/Concept: Gülden Diniz, Duygu Ayaz, Sibel Demir Keçeci; Design: Control/Supervision: Gülden Diniz, Duygu Ayaz; Data Collection and/or Processing: Duygu Ayaz, Sibel Demir Kececi, Gulden Diniz, Sevil Sayhan; Analysis and/or Interpretation: Dudu Solakoglu Kahraman, Sevil Sayhan, Gülden Diniz, Duygu Ayaz; Literature Review: Dudu Solakoglu Kahraman, Duygu Ayaz, Gülden Diniz; Writing the Article: Gülden Diniz, Duygu Ayaz; Critical Review: Duygu Ayaz, Gülden Diniz; References and Fundings: Sevil Sayhan, Duygu Ayaz, Dudu Solakoglu Kahraman; Materials: Sevil Sayhan, Duygu Ayaz, Dudu Solakoglu Kahraman. 


\section{REFERENCES}

1. Lisanti MP, Scherer PE, Tang Z, Sargiacomo M. Caveolae, caveolin and caveolin-rich membrane domains: a signaling hypothesis. Trends Cell Biol. 1994;4(7):231-5. [Crossref] [PubMed]

2. Hurlstone AF, Reid G, Reeves JR, Fraser J, Strathdee G, Rahilly M, et al. Analysis of the Caveolin-1 gene at human chromosome $7 q 31.1$ in primary tumors and tumor-derived cell lines. Oncogene. 1999;18(10):1881-90. [Crossref] [PubMed]

3. Razani B, Woodman SE, Lisanti MP. Caveolae: from cell biology to animal physiology. Pharmacol Rev. 2002;54(3):431-67. [Crossref] [PubMed]

4. Kalluri R, Zeisberg M. Fibroblasts in cancer. Nat Rev Cancer. 2006;6(5):392-401. [Crossref] [PubMed]

5. Witkiewicz AK, Dasgupta A, Sotgia F, Mercier I, Pestell RG, Sabel M, et al. An absence of stromal caveolin-1 expression predicts early tumor recurrence and poor clinical outcome in human breast cancers. Am J Pathol. 2009;174(6):2023-34. [Crossref] [PubMed] [PMC]

6. Huang CF, Yu GT, Wang WM, Liu B, Sun ZJ. Prognostic and predictive values of SPP1, PAI and caveolin-1 in patients with oral squamous cell carcinoma. Int J Clin Exp Pathol. 2014;7(9):6032-9. [PubMed]

7. Chatterjee M, Ben-Josef E, Thomas DG, Morgan MA, Zalupski MM, Khan G, et al. Caveolin-1 is associated with tumor progression and confers a multi-modality resistance phenotype in pancreatic cancer. Sci Rep. 2015;5:10867. [Crossref] [PubMed] [PMC]

8. Sayhan S, Diniz G, Karadeniz T, Ayaz D, Kahraman DS, Gokcu M, et al. Expression of caveolin-1 in peritumoral stroma is associated histological grade in ovarian serous tumors. Ginekol Pol. 2015;6(6):424-8. [Crossref] [PubMed]

9. Eliyatkin N, Aktas S, Diniz G, Ozgur HH, Ekin ZY, Kupelioglu A. Expression of stromal Caveolin- 1 may be a predictor for aggressive behaviour of breast cancer. Pathol Oncol Res. 2018;24(1):59-65. [Crossref] [PubMed]
10. Aydın HA, Bayramoğlu Z, Erdoğan G, Peştereli E, Şimşek T. Comparison oft he immunohistochemical staining of lumican in endometrioid-type endometrial cancer and endometrial intraepithelial neoplasias. JCOG. 2019;29(2):50-6. [Crossref]

11. Bansal N, Yendluri V, Wenham RM. The molecular biology of endometrial cancers and the implications for pathogenesis, classification, and targeted therapies. Cancer Control. 2009;16(1):8-13. [Crossref] [PubMed]

12. Kurman RJ, Carcangiu ML, Herrington CS, Young RH. WHO classification of tumours of female reproductive organs. In: Zaino $\mathrm{R}$, Carinelli SG, Ellenson LH, Eng G, Karabuchi $\mathrm{H}$, Kanishi I, eds. Epithelial Tumours and Precursors. $4^{\text {th }}$ ed. France: IARC; 2014. p.125-35.

13. Trimble CL, Kauderer J, Zaino R, Silverberg S, Lim PC, Burke JJ 2nd, et al. Concurrent endometrial carcinoma in women with a biopsy diagnosis of atypical endometrial hyperplasia: Gynecologic Oncology Group study. Cancer. 2006;106(4):812-9. [Crossref] [PubMed]

14. Diaz-Valdivia N, Bravo $D$, Huerta $H$, Henriquez S, Gabler F, Vega M, et al. Enhanced caveoli1 expression increases migration, anchorageindependent growth and invasion of endometrial adenocarcinoma cells. BMC Cancer. 2015;15(463):1-11. [Crossref] [PubMed] [PMC]

15. Lee SW, Reimer CL, Oh P, Campbell DB, Schnitzer JE. Tumor cell growth inhibition by caveolin re-expression in human breast cancer cells. Oncogene. 1998;16(11):1391-7. [Crossref] [PubMed]

16. Bender FC, Reymond MA, Bron C, Quest AF Caveolin-1 levels are down-regulated in human colon tumors, and ectopic expression of caveolin-1 in colon carcinoma cell lines reduces cell tumorigenicity. Cancer Res. 2000;60(20):5870-8. [PubMed]

17. Fiucci G, Ravid D, Reich R, Liscovitch M. Caveolin-1 inhibits anchorage-independent growth, anoikis and invasiveness in MCF-7 human breast cancer cells. Oncogene. 2002;21(15):2365-75. [Crossref] [PubMed]

18. Quest AF, Leyton L, Párraga M. Caveolins, caveolae, and lipid rafts in cellular transport, signaling, and disease. Biochem Cell Biol. 2004;82(1):129-44. [Crossref] [PubMed]

19. Núñez-Wehinger S, Ortiz RJ, Díaz N, Díaz J, Lobos-González L, Quest AF. Caveolin-1 in cell migration and metastasis. Curr Mol Med. 2014;14(2):255-74. [Crossref] [PubMed]

20. Ayala G, Morello M, Frolov A, You S, Li R, Rosati $F$, et al. Loss of caveolin-1 in prostate cancer stroma correlates with reduced relapse-free survival and is functionally relevant to tumour progression. $\mathrm{J}$ Pathol. 2013;231(1):77-87. [Crossref] [PubMed] [PMC]

21. Tuxhorn JA, McAlhany SJ, Dang TD, Ayala GE, Rowley DR. Stromal cells promote angiogenesis and growth of human prostate tumors in a differential reactive stroma (DRS) xenograft model. Cancer Res. 2002;62(11):3298-307. [PubMed]

22. Campbell L, Gumbleton M, Griffiths DF Caveolin-1 overexpression predicts poor disease-free survival of patients with clinically confined renal cell carcinoma. $\mathrm{Br} \mathrm{J}$ Cancer. 2003;89(10):1909-13. [Crossref] [PubMed] [PMC]

23. Paskaš S, Janković J, Marečko I, Išić Denčić T, Tatić S, Cvejić D, et al. Caveolin-1 expression in papillary thyroid carcinoma: correlation with clinicopathological parameters and BRAF mutation status. Otolaryngol Head Neck Surg. 2014;150(2):201-9. [Crossref] [PubMed]

24. Senetta R, Stella G, Pozzi E, Sturli N, Massi D, Cassoni P. Caveolin-1 as a promoter of tumour spreading: when, how, where and why. J Cell Mol Med. 2013;17(3):325-36. [Crossref] [PubMed] [PMC]

25. Goetz JG, Minguet S, Navarro-Lérida I, Lazcano JJ, Samaniego R, Calvo E, et al. Biomechanical remodeling of the microenvironment by stromal caveolin-1 favors tumor invasion and metastasis. Cell. 2011;146(1):148-63. [Crossref] [PubMed] [PMC]

26. Hecht JL, Mutter GL. Molecular and pathologic aspects of endometrial carcinogenesis. J Clin Oncol. 2006;24(29):4783-91. [Crossref] [PubMed] 